(1)

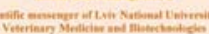

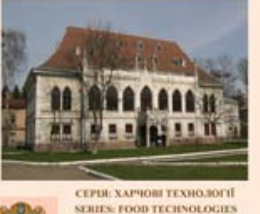

Том 21 Nis 91

2019

Науковий вісник Львівського національного університету ветеринарної медицини та біотехнологій імені С.3. Гжицького. Серія: Харчові технології

Scientific Messenger of Lviv National University of Veterinary Medicine and Biotechnologies.

Series: Food Technologies

ISSN 2519-268X print

https://nvlvet.com.ua/index.php/food

doi: 10.32718/nvlvet-f9111

UDC 664.696-021.362:546.15:613.62

\title{
The prophylactic granola development with increased iodine content
}

\author{
I. Kalugina, N. Dzyuba, I. Yakymenko \\ Odessa National Academy of Food Technologies, Odessa, Ukraine
}

Article info

Received 21.01.2019

Received in revised form 18.02 .2019

Accepted 19.02.2019

Odessa National Academy of Food Technologies, Kanatna Str., 112, Odesa, 65039, Ukraine. Tel.: +38-067-771-17-00 E-mail:ik101273@gmail.com
Kalugina, I., Dzyuba, N., \& Yakymenko, I. (2019). The prophylactic granola development with increased iodine content. Scientific Messenger of Lviv National University of Veterinary Medicine and Biotechnologies. Series: Food Technologies, 21(91), 60-68. doi: 10.32718/nvlvet-f9111

The article is dedicated to development of dry breakfasts meals technology with a high nutritional value in order to prevent iodine deficit and its unfavorable affects in Ukrainian nation. The research purpose is a scientific justification and development a new recipe composition and technology of a new prophylactic dish - granola with increased iodine content. The implementation became possible due to successful combination, in terms of nutrient content optimization in the new dish recipe from natural raw material with high nutritional value, as candied feijoa, honey, oat flakes, sesame seeds, flax, pumpkin, sunflower and chia. The article substantiates the feasibility of producing and introducing innovative dry-breakfast production technologies, including granola, using iodine-containing plant components, namely candied feijoa, since this will solve an important problem of the iodine deficiency and other important essential nutrients in diets, as well as increase of efficiency their digestibility, which will improve the population health. Feijoa fruits contain almost a daily dose of iodine (70-100 $\mu \mathrm{g} / 100 \mathrm{~g})$ and a complex of biologically active substances. The potassium iodide is a very unstable compound, it destroys as a result of temperature rise, which leads to significant iodine los. Owing to this, in order to maximize the useful properties of Feijoa fruits in the production of candied fruits, we used a savvy technology of infrared drying at relatively low temperatures $(T=$ $55-60{ }^{\circ} \mathrm{C}$ ) in AVERNO drier. To form a clearer and more complete picture of the candied feijoa influence on the change of the new dish properties, there were developed recipient granola formulations, containing this fruit component in the amount of $22 \%$ to the mass of the finished dish, as well as without it. The study's results have shown that the candied feijoa adding improves the organoleptic characteristics of the granola. It was established that,due to the addition of candiedfaijoa, the granola's titrated acidity increases by more than 2.6 times. Thehumidity of granola samples with candied feijoa is increased by $6.8 \%$ and is within the recommended limits for a dry fruit breakfast. It has been proved that the candied feijoa granola addition in the formulation allows the product to be substantially enriched with iodine. Thus, iodine content in candied feijoagranola is $26 \mu \mathrm{g} / 100 \mathrm{~g}$. Based on the comparative analysis of the organoleptic, physicochemical and microbiological parameters, the optimum ratio of the recipe components was substantiated and the technology of prophylactic granola with high iodine content was developed.

Key words: feijoa, granola, candied fruits, prophylactic foods, organoleptic parameters, high iodine content.

\section{Розробка технології граноли профілактичного призначення 3 підвищеним вмістом йоду}

I.М. Калугіна, Н.А. Дзюба, І.О. Якименко

Одеська національна академія харчових технологій, м. Одеса, Украӥна

Стаття присвячена розробичі технології сухих сніданків підвищеної харчової иінності для профілактики дефіичту йоду та його несприятливих наслідків у населення України. Метою дослідження є наукове обтрунтування і розробка рецептурної композиції та технології нової страви профілактичного призначення - граноли з підвищеним вмістом йоду. Реалізація поставленої мети стала можливою завдяки вдалому поєднанню з точки зору оптимізації нутрієнтного складу в рецептурі нової страви натуральної сировини підвищеної поживної цінності, такої як иукати фейхоа, меду, вівсяних пластівців, насіння кунжуту, льону, гарбуза, 
соняшнику та чіа. В статті обтрунтовано доцільність виробництва і впровадження інноваційних технологій виробництва сухих сніданків, в тому числі граноли, з використанням йодовмісних рослинних компонентів, а саме иукатів фейхоа, оскільки изе дозволить вирішити важливу проблему дефіциту йоду та інших важливих ессенціальних нутрієнтів в харчових раціонах, а також підвищення ефективності їх засвоюваності, щзо сприятиме поліпшенню стану здоров'я населення. Адже плоди фейхоа містять майже добову норму йоду (70-100 мкг/100 г) та комплекс біологічно-активних речовин. Оскільки йодид калію є дуже нестійкою сполукою, руйнується в результаті підвищення температури, шуо призводить до значних втрат йоду, то для максимального збереження корисних властивостей плодів фейхоа при виробництві иукатів застосовували ощадну технологію інфрачервоної сущки при порівняно низьких температурах $\left(T=55-60^{\circ} \mathrm{C}\right)$ в сушильній шафі AVERNO. Для формування більш чітких і повних уявлень про вплив иукатів фейхоа на зміну властивостей нової страви були розроблені рецептурні композиції граноли, які містили июю фруктового компоненту у кількості 25\% до маси готової страви, а також без неї. Результати досліджень показали, ицо додавання иукатів фейхоа поліпшує органолептичні показники граноли. Встановлено, шео з додаванням иукатів фейхоа титрована кислотність граноли збільшується більш ніж в 2,6 разу. Вологість зразків граноли із введенням иукатів фейхоа підвищується на 6,8\% й перебуває у рекомендованих межах для сухих сніданків з фруктами. Доведено, щяо додавання у рецептуру граноли иукатів фейхоа дозволяє суттєво збагатити продукт йодом. Так, вміст йоду в гранолі з иукатами фейхоа становить 26 мкг/100 г. На основі порівняльного аналізу органолептичних, а фізико-хімічних та мікробіологічних показників обтрунтовано оптимальне співвідношення рецептурних компонентів та розроблено технологію граноли профілактичного призначення з підвищеним вмістом йоду.

Ключові слова: фейхоа; гранола; иукати; страви профілактичного призначення, органолептичні показники; підвищений вміст uัody.

\section{Вступ}

Розробка нових харчових продуктів для різних груп населення - актуальне завдання в рішенні проблеми здорового харчування. Важливу роль в сучасних дослідженнях відіграє розробка продуктів профілактичного призначення, які здатні покращувати функціонування як певних органів і систем людини, так і всього організму загалом.

Дефіцит мікронутрієнтів викликає серйозні порушення обміну речовин і важкі хронічні захворювання. В останні роки дуже гостро постала проблема захворювань, пов'язаних з нестачею надходження йоду в організм людини, що викликає йододефіцитні захворювання. Це залишається однією з серйозних проблем збереження здоров'я населення в усьому світі, в зв'язку з цим створено ряд міжнародних організацій, які займаються вирішенням цієї проблеми: Всесвітня організація охорони здоров'я, Дитячий фонд $\mathrm{OOH}$, Міжнародна рада 3 контролю за йододефіцитними захворюваннями.

За оцінкою ВООЗ і ЮНІСЕФ, понад мільярд людей у світі мають ризик розвитку йододефіцитних захворювань, 300 млн людей - збільшення щитовидної залози, 30 млн страждають на кретинізм. Саме тому пріоритетні міжнародні програми містять заходи щодо профілактики і контролю за йододефіцитними захворюваннями поряд 3 програмами боротьби зі СНІДом, поліомієлітом, туберкульозом (Suplotova et al., 2018).

Результати досліджень йодної забезпеченості населення України за останні десять років свідчать про наявність на території країни йодної недостатності різного ступеня - від легкої до важкої. В Україні на ендемічних щодо йоду територіях проживає близько третини населення (Nazarov, 2003). Проблема посилюється негативними змінами в структурі харчування українців, особливо соціально незахищених груп населення. Незважаючи на наявність в країні доступу до моря, в нових економічних умовах споживання багатих йодом риби і морепродуктів різко зменшилося.

Йод є життєво важливим мікроелементом, який бере участь у функціонуванні щитовидної залози, забезпечуючи утворення гормонів тироксину і трийодтироніну. Необхідний він для росту клітин всіх тканин організму людини, мітохондріального дихання, регуляції мембранного транспорту натрію і гормонів. Недостатнє надходження йоду призводить до ендемічного зобу з гіпотиреозом і уповільнення обміну речовин, гіпотензії, відставання в рості й розумовому розвитку у дітей (Hetzel, 1983).

Проблема йодного дефіциту надзвичайно актуальна, оскільки понад 70\% густонаселених територій країни мають нестачу йоду у воді, грунті та продуктах харчування місцевого походження (Рopova, 2004).

Основний метод профілактики йододефіцитних захворювань - йодування продуктів харчування. У всьому світі для цього використовують кухонну сіль, додаючи до неї йодат калію з розрахунку 40 мг $\mathrm{KIO}_{3}$ на 1 кг продукту. Розподіл і вживання йодованої солі в більшості європейських країн базується на принципах добровільності та є обов'язковим в Австрії, Болгарії, Чехії, Словаччини, Угорщини, Португалії (в ендемічних районах), Югославії. За оцінкою ВООЗ, відсутність йодування солі в країні або недостатній його рівень є однією з глибинних причин, що викликають фізіологічні порушення, пов'язані з недостатністю йоду в організмі (Suplotova et al., 2018).

Крім йодування солі існує практика йодування хліба і хлібобулочних виробів, молока, масла з використанням неорганічних сполук йоду, продуктів переробки морських водоростей, дріжджових культур, вирощених на йодованій воді та ін. (Korzun et al., 2008). Недоліком йодованих продуктів $€$ наявність специфічних органолептичних характеристик і нестабільного мікронутрієнтного складу, недостатній рівень йоду, що біологічно засвоюється, оскільки багатьма розробниками не враховуються непрямі метаболічні фактори біологічної дії йоду в організмі. Також відомо, що йодид калію є дуже нестійкою сполукою, руйнується в результаті підвищення температури, що призводить до значних втрат йоду (Suplotova et al., 2018). 3 цього можна зробити висновок, що технологія виробництва продуктів, збагачених йодом, повинна бути розроблена таким чином, щоб максимально зберегти його масовий вміст в продукті. 
Йодування сухих сніданків $є$ перспективним та актуальним, оскільки популярність цієї групи продукції як обов'язкового компонента здорового харчування у населення зростає 3 кожним роком. Саме тому асортимент сухих сніданків найчастіше розширюється за рахунок створення нових продуктів дієтичного й профілактичного призначення. Розробляються нові види сухих сніданків спеціального призначення для дієтичного лікувального і профілактичного харчування 3 низькою калорійністю, збалансованою харчовою цінністю, низькимглікемічним індексом тощо.

Згідно з чинної документації в Україні сухі сніданки за зовнішнім виглядом поділяють на зернові пластівці, повітряні зерна, круп'яні палички, круп'яні батончики, фігурні вироби. Сьогодні до сухих сніданків зараховують ще й мюслі та гранолу.

За використовуваною зерновою сировиною сухі сніданки діляться на кукурудзяні, вівсяні, рисові, пшеничні. Залежно від особливостей виробництва сухі сніданки бувають: неглазуровані або глазуровані; з добавками і без добавок (Sakibaev et al., 2016).

Залежно від рецептури в сухі сніданки вносять різні смакові добавки: сіль, цукор, рослинну олію, прянощі, подрібнені сухофрукти і горіхи. Використання як сировини широкого переліку продуктів дозволяе виробляти асортимент продуктів для різних категорій споживачів.

Встановлено, що в 100 г сухих сніданків міститься від 5 до 12\% білків, 0,2 - 20\% жирів, 52 - 80\% вуглеводів. Білки, жири і вуглеводи, які містяться в сухих сніданках, перебувають у формі, легко засвоюваній організмом людини. У сніданках також міститься цілий комплекс вітамінів i мінеральних речовин, вкрай необхідних організму людини (Sakibaev et al., 2016). Профілактичної спрямованості сухі сніданки набувають в процесі збагачення розчинними харчовими волокнами і вітамінами за рахунок застосування пребіотиків і зернової сировини (Usenja \& Filatova, 2015).

Крім того, для збагачення цих продуктів харчування використовуються нетрадиційні види сировини, серед яких широке застосування мають пшеничні висівки, зернові та круп'яні продукти, вівсяні пластівці, соєві продукти, суха морська капуста, целюлоза та ін., що містять в своєму складі більше білка, вітамінів групи Е, В, фолієвої кислоти, мінеральних речовин (Hurrell, 2002).

Отже, сьогодні харчова індустрія більшості країн світу починає переорієнтовуватися на створення харчових продуктів харчування, збагачених функціональними інгредієнтами рослинного походження, які повинні регулярно надходити в організм людини. Щоденне споживання таких продуктів справляє позитивний вплив на організм людини, наприклад: поліпшує функції імунного захисту, запобігає різним захворюванням, контролює фізичні і психічні відхилення в організмі людини.

Таким чином, існуюча проблема харчування людини і нестача корисних речовин в організмі спонукає харчову галузь до створення корисних, здорових i збагачених ессенціальними нутрієнтами, в тому числі йодом, продуктів харчування.
Для профілактики захворювань, зумовлених дефіцитом йоду, перспективним є підвищення його вмісту в харчових продуктах в результаті комплексного використання харчової сировини, в якій йод перебуває в хімічно зв'язаному з органічними сполуками стані. Відомо, що на відміну від неорганічного, йод органічних сполук краще засвоюється, а його надлишки легко евакуюються з організму без утворення токсичних ефектів (дифузного токсичного зобу). При цьому організм засвоює лише ту кількість йоду, яка йому необхідна. В зв'язку з цим перспективним напрямком в вирішенні проблеми йододефіциту населення України $є$ розробка технологій нових харчових продуктів профілактичного призначення, таких як гранола 3 підвищеним вмістом біодоступного йоду, шляхом використання рослинної сировини багатої на йод.

Метою дослідження є наукове обгрунтування і розробка технології сухих сніданків профілактичного призначення типу граноли шляхом використання нової для України сировини з підвищеним вмістом йоду-фейхоа.

Для досягнення мети булу визначені такі завдання:

1. Обгрунтуваннядоцільностірозробкитехнології виробництва сухих сніданків типу граноли з підвищеним вмістом йоду для вирішення проблеми йододефіциту у населення.

2. Моніторинг рослинної сировини на предмет збалансованості іï хімічного складу на вміст цінних біологічно активних речовин, ессенціальних нутрієнтів, в тому числі на йоду у біодоступній формі, органолептичних та технологічних характеристик та можливості її використання у технології граноли.

3. Моделювання рецептурного складу граноли 3 урахуванням харчової цінності готового продукту, органолептичних та фізико-хімічних показників якосTi.

4. Визначення зміни фізико-хімічних та органолептичних показників якості граноли з додаванням фейxoa.

5. Розробка технології виробництва граноли з підвищеним вмістом йоду.

\section{Матеріал і методи досліджень}

Було розробленоінноваційну технологію виробництва сухих сніданків, а саме граноли, з використанням йодовмісної рослинної добавки - цукатів фейхоа. Для максимального збереження корисних властивостей плодів фейхоа при виробництві цукатів застосовували ощадну технологію інфрачервоної сушки при порівняно низьких температурах $\left(\mathrm{T}=55-60{ }^{\circ} \mathrm{C}\right)$ в сушильній шафі AVERNO.

Були розроблені рецептурні композиції граноли, які містили цю фруктового компоненту у кількості 25\% від маси готової страви, а також без неї.

У цій роботі були використані стандартні методи дослідження органолептичних та фізико-хімічних властивостей продукту (DSTU 4634:2006, 2007). Вміст йоду визначали титрометричним методом (DSTU-P 4588:2006, 2006). 


\section{Результати та їх обговорення}

Реалізація поставленої мети можлива завдяки вдалому поєднанню з точки зору оптимізації нутрієнтного складу у рецептурі нової страви натуральної сировини підвищеної харчової цінності, в тому числі багатої на йод.

Формування спрямованих профілактичних властивостей харчовихпродуктів пов'язане 3 пошуком і використанням нових джерел сировини, що відрізняється високою харчовою цінністю, а також застосуванням сучасних технологічних прийомів, що дозволяють істотно впливати на органолептичні і фізикохімічні показники готової продукції.

При розробці технології страв для профілактики захворювань, зумовлених дефіцитом йоду, перспективним $є$ підвищення його вмісту в харчових продуктах в результаті комплексного використання харчової сировини, в якій йод міститься в хімічно зв'язаному 3 органічними сполуками стані.

Було проведено моніторинг рослинної сировини на предмет збалансованості іiі хімічного складу на вміст цінних біологічно активних речовин, в тому числі йоду, органолептичних та технологічних характеристик та можливості іiі використання у технології граноли.

Найбільш вивченими і часто використовуваними джерелами органічного йоду є продукти моря, багаті йодом, такі як риба, гребінці, краби і морські водорості: ламінарія, спіруліна, фукус і цистозіра чорноморська, а також йодоказеїн, застосування якого як добавки в харчові продукти виключає передозування йоду в організмі людини (Pilipenko \& Pilipenko, 2007; Ershow et al., 2018; Trøan et al., 2018).

Природним джерелом йоду є і ламінарія, яка містить велику кількість йоду (в середньому до 0,3\% від сухої ваги), який міститься в комплексі з супутніми для кращого засвоєння організмом речовинами, такими як селен, залізо, цинк, мідь (Mišurcová et al., 2011; Mendis \& Kim, 2011; Moroney et al., 2013; Cofrades et al., 2013; Roohinejad et al., 2017).

Як перспективне джерело йоду розглядалися різні частини волоського горіха (Tonacchera et al., 2013).

Однак продукти переробки морських водоростей та волоських горіхів мають специфічний смак і запах, що ускладнює їх використання як йодовмісних добавок у солодких сухих сніданках типу граноли.

Тому як йодовмісну добавку в розробці технології граноли профілактичного призначення було обрано нову сировину для України - фейхоа.

Фейхоа - єдина рослина, яку за вмістом йоду можна порівняти 3 морепродуктами. Особливість цієї рослини така, що вона здатна накопичувати водорозчинні сполуки йоду (близько 70-100 мкг в 100 г продукту), які легко засвоюються організмом людини. Це майже добова потреба людини у йоді, адже відомо, що фізіологічна потреба дорослої людини в йоді становить близько 150 мкг на добу (Recommended iodine levels in salt..., 1996). Тому, вживання плодів фейхоа дуже корисно для людей, які проживають в йододефіцитних регіонах, а також для профілактики хвороб щитовидної залози (Golubeva et al., 2015).
Плоди фейхоа характеризуються високим вмістом пектинових речовин (9-12\%). Це дозволяє зробити висновок про доцільність використання цього виду сировини для виробництва пектиновмісних харчових виробів. Також плоди фейхоа містять ряд цінних біологічно активних речовин, що визначають їх лікувальні та дієтичні властивості (Tipsina et al., 2008). Так, в зрілих плодах міститься від 20 до 44 мг/100 г вітаміну C, масова частка якого збільшується в міру дозрівання плодів (Kalugina et al., 2017).

Шкірка фейхоа багата антиоксидантами (Fan, 2018). Як відомо, несприятливі зовнішні фактори, такі як: вплив радіації, УФ-опромінення, інфекційні захворювання, стреси, куріння, можуть призводити до зниження роботи антиоксидантної системи організму і підвищення ризику різних захворювань. В той час, зменшенню шкідливого впливу на організм вільних радикалів сприяє систематичне вживання натуральних рослинних продуктів 3 високим вмістом антиоксидантів, таких як фейхоа.

Відомі дані про антимікробну дію водних екстрактів з фейхоа (Sosjura et al., 2013).

В плодах фейхоа містяться такі біологічно активні речовини як кахетіни і лейкоантоціани, ефірні олії, які $\epsilon$ потужними антиоксидантами та імуномодуляторами, зменшують ризик виникнення онкологічних захворювань i перешкоджають старінню організму (Kalugina et al., 2018).

Виходячи з того, що ягоди фейхоа мають солодкий смак та пікантний пряний присмак було прийнято рішення щодо розробки на їх основі саме солодких сухих сніданків таких як гранола 3 підвищеним вмістом йоду.

В якості основи для їх виробництва сухих сніданків вибирають різні крупи: вівсяна, толокно, рисова, кукурудзяна, пшенична. Крупи містять широкий набір вітамінів і мінеральних речовин (Ovcharova et al., 2006). Продукти, приготовані з вівса - вівсяна крупа, пластівці - найбільш поживні зі всіх круп і добре засвоюються (100 г містять 350 ккал). Вони багаті мінеральними речовинами і вітамінами. Ліпотропні властивості вівсяних круп обумовлені найбільшим 3 усіх круп вмістом лецитину, лінолевої кислоти, холіну. Вівсяні пластівці містить ненасичені жирні кислоти, відносно велику кількість заліза, слизових речовин (Hu et al., 2014; Sterna et al., 2016). Завдяки високій харчовій цінності саме вівсяні пластівці було обрано основою рецептурної композиції нової страви.

На першому етапі розробки й моделювання рецептурного складу багатокомпонентної суміші для виробництва граноли відбувався підбір сировинних інгредієнтів, з урахуванням їх харчової цінності, функціональних і технологічних властивостей та прогнозованого впливу на зміну органолептичних та фізикохімічних показників якості готового продукту.

На підставі аналізу хімічного складу сировини 3 точки зору оптимізації нутрієнтного складу рецептури нової страви булаобгрунтована доцільність використання натуральної сировини підвищеної харчової цінності, такої як фейхоа, меду, вівсяних пластівців, насіння кунжуту, льону, гарбуза, соняшнику та чіа. 
На другому етапі проводили моделювання складу сумішей за обраними критеріями, що характеризують харчову цінність, і визначали оптимізований склад сумішей. Встановлювали співвідношення різних видів компонентів в суміші, тобто максимальні і мінімальні їх кількості, які служили обмежувальними факторами при моделюванні складу суміші.

Для формування більш чітких і повних уявлень про вплив цукатів фейхоа на зміну властивостей нової страви були розроблені рецептурні композиції граноли, які містили цього фруктового компоненту у кількості 25\% від маси готової страви, а також без неї.

Оскільки йодид калію є дуже нестійкою сполукою, руйнується в результаті підвищення температури, що призводить до значних втрат йоду, то для максимального збереження корисних властивостей плодів фейхоа при виробництві цукатів застосовували ощадну технологію інфрачервоної сушки при порівняно низьких температурах $\left(\mathrm{T}=55-60{ }^{\circ} \mathrm{C}\right)$ в сушильній шафі AVERNO.

Для приготування дослідних зразків граноли перелічені компоненти брали в такому співвідношенні, мас.\%: вівсяні пластівці - 16-31; цукати фейхоа - 025 ; насіння соняшника $-8-14$; насіння гарбуза $-8-14$; насіння чіа $-8-14$; насіння льону $-8-14$; насіння кунжуту - 8-14; мед - 5; масло вершкове - 3,9; кориця 0,1 (рис. 1).

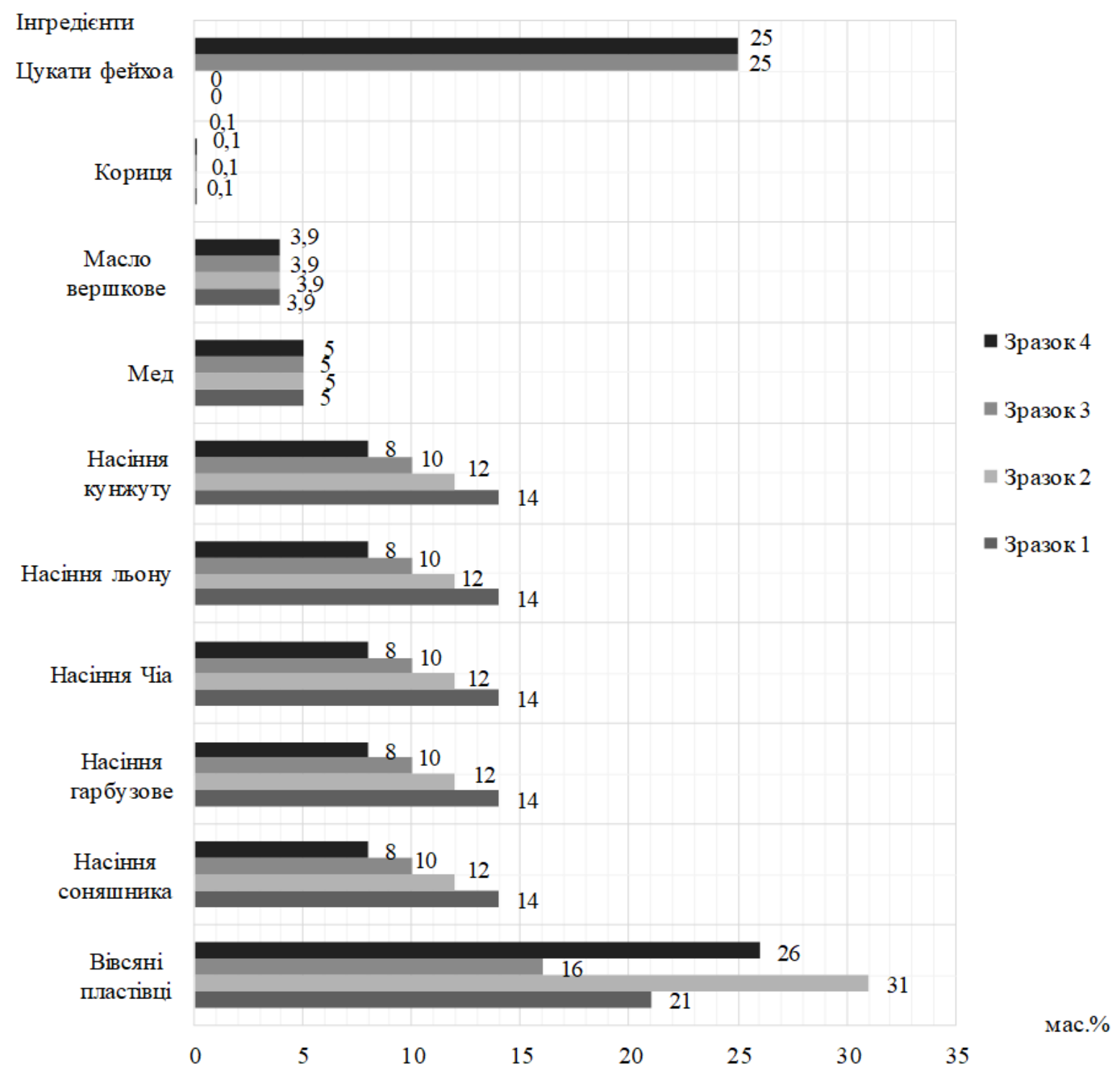

Рис. 1. Співвідношення інгредієнтів у рецептурі граноли, мас. \%

3 рис. 1 бачимо, що масова доля рецептурних інгредієнтів у всіх зразках різна, зразки 1 та 2 не містять цукатів фейхоа зовсім, це контрольні зразки.

Функціональна схема приготування граноли профілактичного призначення подана на рис. 2.

Дані узагальнених експертних оцінок органолептичного аналізу зразків граноли показані на рис. 3 .
Аналіз приведеної порівняльної діаграми (рис. 3.) свідчить про кращі органолептичні показники зразків граноли $з$ цукатами фейхоа (зразки 3 та 4) порівняно 3 контрольними зразками 1 та 2. Так, зразки граноли 3 та 4 з 25\% вмістом цукатів фейхоа характеризується найкращими показниками смаку, запаху, консистенції та в загальній оцінці отримують більш високі бали. 
Проте такі важливі показники якості зразків граноли 3 фейхоа як зовнішній вигляд та колір все ж потребують корекції.
Важливим показником якості граноли є вологість, від вмісту якої залежать органолептичні показники страви, эї вихід та тривалість зберігання.

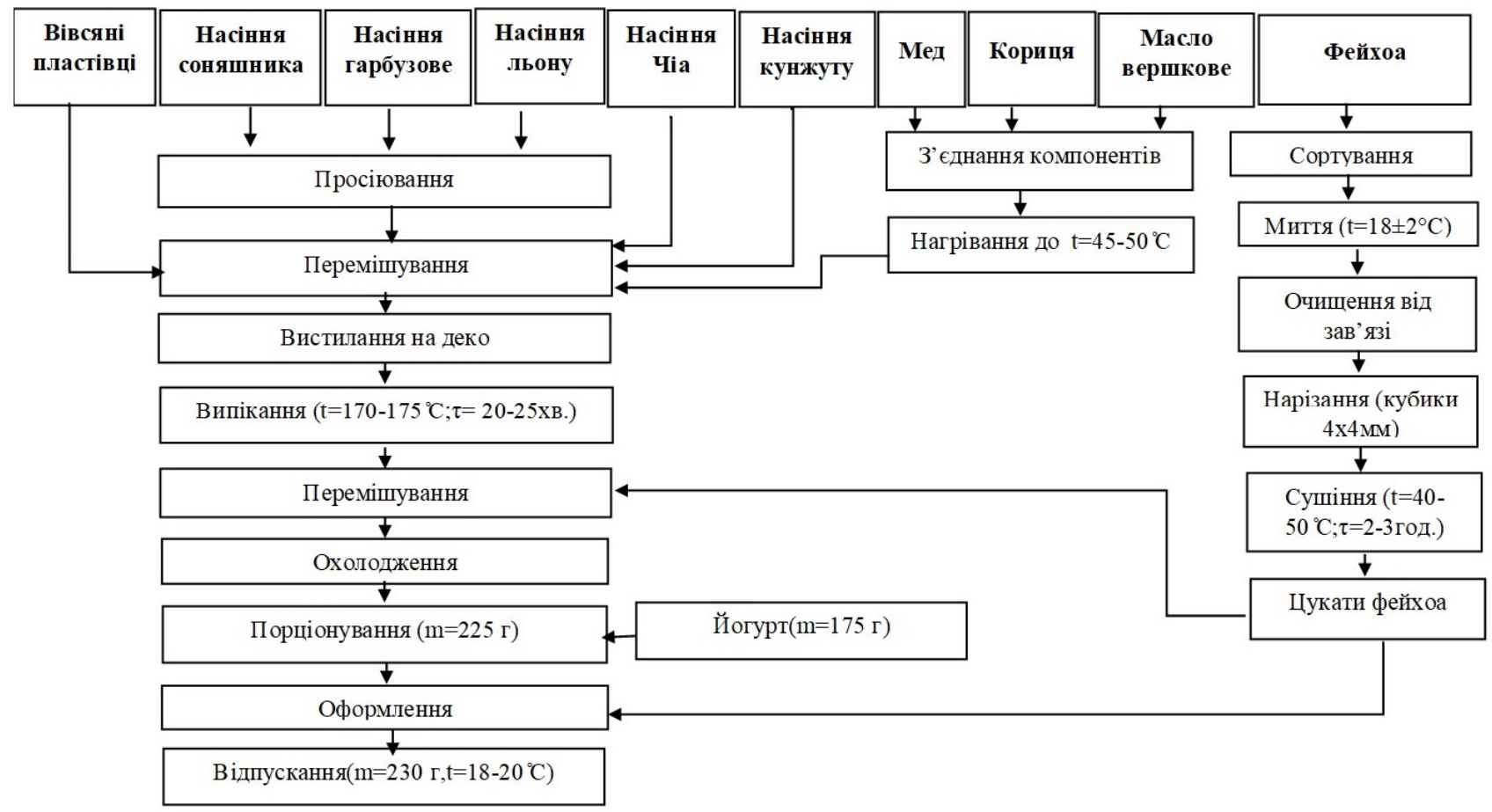

Рис. 2. Функціональна схема приготування граноли профілактичного призначення

Зовнішній вигляд
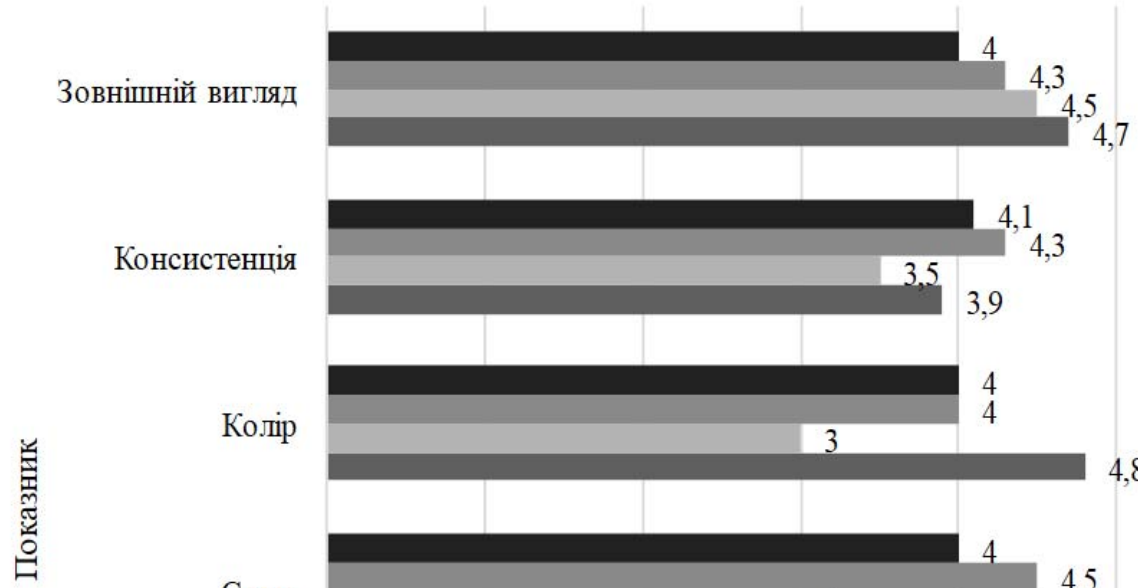

Смак

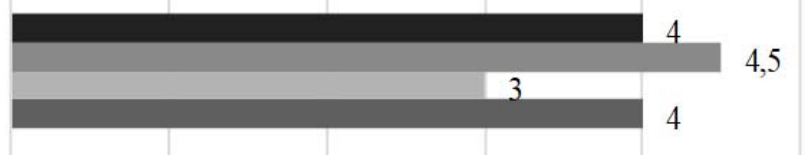

Запах

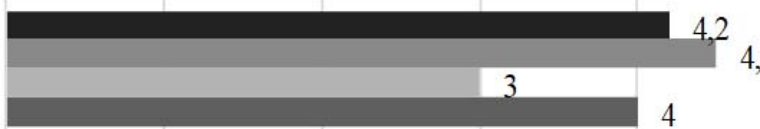

Загальна оцінка
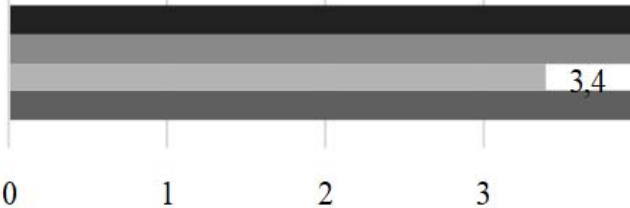

4,06

4,32

4,28

4

5

Оцінка

- Зразок 3

- Зразок 2

Шразок 1

Рис. 3. Порівняльна діаграма органолептичних показників зразків граноли 


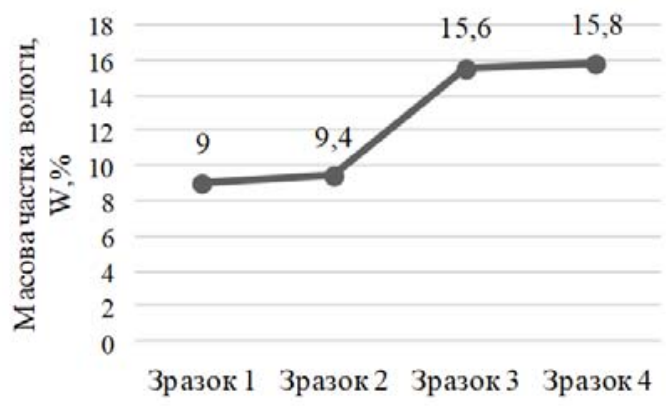

Рис. 4. Залежність вмісту вологи, W,\% від рецептурного складу граноли

3 даних, які показано на рис. 4. бачимо, що масова частка вологи в гранолі з додаванням цукатів фейхоа збільшується приблизно на $6,8 \%$, але є у рекомендованих межах для сухих сніданків $з$ фруктами.

Встановлено, що з додаванням цукатів фейхоа титрована кислотність граноли збільшується більш ніж в 2,6 разу (рис. 5). Це пов'язано з тим, що у рецептуру нового сухого сніданку додається інгредієнт із порівняно високою кислотністю - адже у цукатах фейхоа міститься від 20 до 44 мг/100 г вітаміну С. Цей факт не може не впливати на органолептичні показники готового продукту - так, з додаванням цукатів фейхоа гранола набуває приємного кислого присмаку.

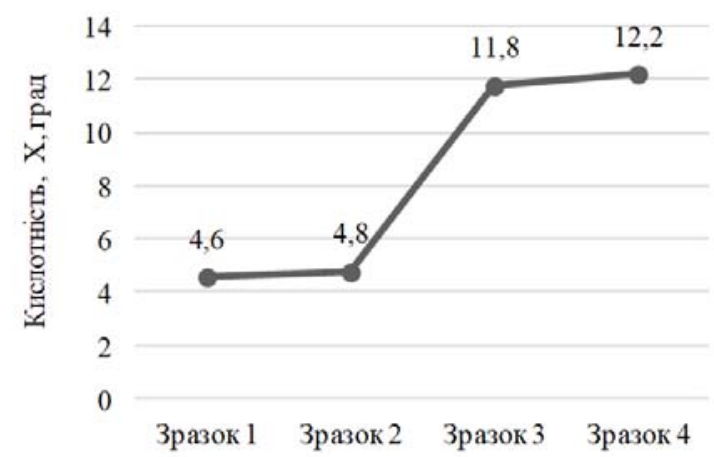

Рис. 5. Залежність титрованої кислотності, X, градвід рецептурного складу граноли

При створенні продукції харчування профілактичної спрямованості з підвищеним вмістом йоду головним критерієм оцінки служить вміст останнього в готовому продукті.

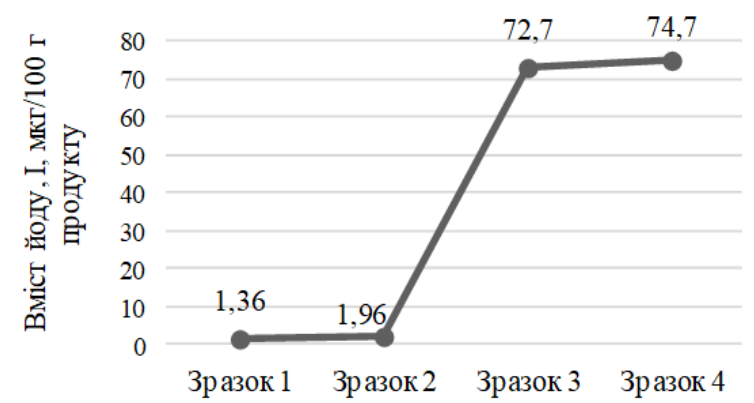

Рис. 6. Залежність вмісту йоду, I, мкг/100 г продукту від рецептурного складу граноли.
3 рисунку 6 видно, що 3 введенням добавки фейхоа вміст йоду в гранолі суттєво збільшується - у 55 разу, і становить 72,7-74,7 мкг/100 г. Таким чином, вживання порції граноли 3 цукатами фейхоа (100 г) здатне забезпечити організм людини майже $50 \%$ добової норми щоденного вживання йоду, яка рекомендована ЮНІСЕФ, МРКЙДЗ (20) та ВООЗ (21).

\section{Висновки}

Таким чином, на основі об'єктивного аналізу стану проблеми дефіциту йоду і ессенціальних нутрієнтів в харчових раціонах населення України та шляхів iii вирішення зроблено висновок про доцільність виробництва і впровадження інноваційної технології виробництва граноли профілактичного призначення 3 використанням цінної рослинної сировини, що містить йод.

На підставі моніторингу рослинної сировини на предмет збалансованості іiі хімічного складу на вміст цінних речовин, в тому числі йоду, органолептичних та технологічних характеристик прийнято рішення щодо розробки технології сухих сніданків, таких як гранола, з такою перспективною сировиною, багатою на йод, як фейхоа.

На основі порівняльного аналізу органолептичних та фізико-хімічних показників зразків граноли з різним співвідношення інгредієнтів у рецептурі обгрунтовано рецептурний склад, режими основних процесів обробки сировини та розроблено технологію граноли 3 фейхоа.

Доведено, що готовий продукт - гранола з вмістом добавки цукатів фейхоа у кількості $25 \%$ від загальної маси продукту характеризується високим вмістом йоду у біодоступній формі, має високу харчову цінність та добрі споживчі показники, що дозволяє рекомендувати його до споживання у профілактичному харчуванні.

Перспективи подальших досліджень. Таким чином, розробка страв 3 підвищеною харчовою цінністю із нової і нетрадиційної сировини з високим вмістом біологічно активних речовин, в тому числі йоду, є ефективною і доступною для реалізації програмою зміцнення здоров'я, підтримки працездатності і активного довголіття населення України. Особливо перспективною для розробки продуктів спеціального та профілактичного призначення є така популярна група у асортименті страв сучасної людини, як сухі сніданки, а саме такий “модний” їхній різновид, як гранола. Водночас наукових досліджень зі збагачення сухих сніданків йодом шляхом додавання у рецептуру йодовмісної сировини - обмежена кількість. Тому подальші розробки з розширення асортименту сухих сніданків типу гранола 3 підвищеною біологічною цінністю та поліпшеними споживчими властивостями $\epsilon$ перспективним напрямком. Крім того, потребує подальшого вивчення впливу технологічних факторів на втрати йоду для розробки режимів обробки сировини та технології виробництва готових продуктів 3 максимального збереженим складом біологічно активних речовин. 
Отже, використання нетрадиційної ягідної сировини - фейхоа дає змогу розширити асортимент солодких страв 3 підвищеною біологічною цінністю та поліпшених споживних властивостей, тим самим удосконалити структуру харчування населення України.

\section{References}

Cofrades, S., Serdaroğlu, M., \& Jiménez-Colmenero, F. (2013). Design of healthier foods and beverages containing whole algae: Chapter 19. S. Cofrades,. Functional Ingredients from Algae for Foods and Nutraceuticals; Woodhead Publishing Series in Food Science, Technology and Nutrition, 609-633. doi: 10.1533/9780857098689.4.609.

DSTU 4634:2006 (2007). Kontsentraty kharchovi snidanky sukhi plastivtsi krupiani. K.: Derzhspozhyvstandart Ukrainy (in Ukrainian).

DSTU-P 4588:2006 (2006). Vyroby khlibobulochni dlia spetsialnoho diietychnoho spozhyvannia. Derzhspozhyvstandart Ukrainy (in Ukrainian).

Ershow, A.G., Skeaff, S.A., Merkel, J.M., \& Pehrsson, P.R. (2018). Development of Databases on Iodine in Foods and Dietary Supplements. Nutrients, 10(1), 100-120. doi: 10.3390/nu10010100.

Fan, Z. (2018). Chemical and biological properties of feijoa (Acca sellowiana). Trends in Food Science \& Technology, 81, 121-131. doi: 10.1016/j.tifs.2018.09.008.

Golubeva, L.V., Dolmatova, O.I., \& Najdenkina, T.A. (2015). Tvorozhnye produkty $\mathrm{s}$ komponentami rastitel'nogo proishozhdenija. Vestnik Voronezhskogo gosudarstvennogo universiteta inzhenernyh tehnologij, 2, 103-107 (in Russian).

Hetzel, B.S. (1983). Iodine deficiency disorders (IDD) and their eradication. Lancet, 1126-1129. doi: 10.1016/S0140-6736 (83) 90636-0.

Hu, X.-Z., Zheng, J.-M., Li, X., Xu, C., \& Zhao, Q. (2014). Chemical composition and sensory characteristics of oat flakes: A comparative study of naked oat flakes from China and hulled oat flakes from western countries. Journal of Cereal Science, 60(2), 297-301. doi: 10.1016/j.jcs.2014.05.015.

Hurrell, R.F. (2002). Fortification: Overcoming Technical and Practical Barriers. The Journal of Nutrition, 132(4), 806-812. doi: 10.1093/jn/132.4.806S.

Kalugina, I., Telegenko, L., Kalugina, Y., \& Kyselov, S. (2017). The nutritional value of desserts with the addition of Gooseberry family raw materials from the Northern Black Sea Region. Ukrainian Food Journal, 6(3), 459-469. doi: 10.24263/2304-974X-2017-6-3-6.

Kalugina, I.M., Telezhenko, L.M., \& Dzjuba, N.A. (2018). Doslidzhennja strukturi zamorozhenih solodkih strav $\mathrm{z}$ fejhoa. Visnik Nacional'nogo tehnichnogo universitetu "HPI". Serija: Novye tehnologii v nauchnyh processah, 16(1292), 151-156. doi: 10.20998/2413-4295.2018.16.23 (in Ukrainian).

Korzun, V.N. Parats, A.M., Kolesnykov, M.K., \& Hlynka, Z.I. (2008). Yododefitsytni zakhvoriuvannia: novi pohliady na etiolohiiu, patolohiiu ta profilaktyku. Materialy mizhnar. nauk.-prakt. konf "Dovkillia i zdorovia liudyny" (Uzhhorod, 19 kvitnia 2008 r.). Uzhhorod: UzhNU "Hoverla", 115-120 (in Ukrainian).

Mendis, E, \& Kim, S.K. (2011). Present and Future Prospects of Seaweeds in Developing Functional Foods: Chapter 1. Eresha Mendis, Se-Kwon Kim. Advances in Food and Nutrition Research, 64, 1-15. doi: 10.1016/B978-0-12-387669-0.00001-6.

Mišurcová, L., Machů, L., \& Orsavová, J. (2011). Seaweed Minerals as Nutraceuticals: Chapter 29. Advances in Food and Nutrition Research, 64, 371390. doi: 10.1016/B978-0-12-387669-0.00029-6.

Moroney, N.C., O'Grady, M.N., O'Doherty, J.V., \& Kerry, J.P. (2013). Effect of a brown seaweed (Laminaria digitata) extract containing laminarin and fucoidan on the quality and shelf-life of fresh and cooked minced pork patties. Meat Science, 94(3), 304-311. doi: 10.1016/j.meatsci.2013.02.010.

Nazarov, V.P. (2003). Ispol'zovanie koncentrata jelamina dlja proizvodstva produktov povyshennoj biologicheskoj cennosti. Materiali nauk.-prakt. konf. "Harchovi dobavki, ingpedienti, BADi: Ih vlastivosti ta vikoristannja u virobnishhga produktiv i napoiv"; K., 43-44 (in Russian).

Ovcharova, G.P., Abrech, M.Ju., \& Neporozhnjaja, E.Ju. (2006). Suhie zernovye zavtraki dlja detej doshkol'nogo i shkol'nogo vozrasta. Izvestija vuzov. Pishhevaja tehnologija, 1, 46-27 (in Russian).

Pilipenko, T.V., \& Pilipenko, N.I. (2007). Formirovanie kachestva i potrebitel'skih svojstv molochnyh produktov: monografija. SPb: SPbTJeI (in Russian).

Popova, S.B. (2004). Sovershenstvovanie processa sushki tykvy $\mathrm{v}$ tehnologii plodoovoshhnyh koncentratov: avtoref. dis. kand. tehn. nauk. Svetlana Borisovna Popova; M. (in Russian).

Recommended iodine levels in salt and guidelines for monitoring their adequacy and effectiveness. Geneva, World Health Organization, 1996 (WHO/NUT/96.13).

Roohinejad, S., Koubaa, M., Barba, F.J., Saljoughian, S., Amid, M., \& Greiner, R. (2017). Application of seaweeds to develop new food products with enhanced shelf-life, quality and health-related beneficial properties. Food Research International, 99(3), 10661083. doi: 10.1016/j.foodres.2016.08.016.

Sakibaev, K.Sh., Kas'janov, G.I., Shamshiev, B.N., \& Karymshakova, M.U. (2016). Sovershenstvovanie tehnologii suhih zavtrakov. Izvestija Oshskogo tehnologicheskogo universiteta, 2, 184-188 (in Russian).

Sosjura, E.A., Guguchkina, T.I., \& Burcev, B.V. (2013). Ispol'zovanie plodov fejhoa $\mathrm{i}$ ezheviki dlja proizvodstva napitkov. Pishhevaja promyshlennost', 7, 57-59 (in Russian).

Sterna, V., Zute, S., \& Brunava, L. (2016). Oat Grain Composition and its Nutrition Benefice. Agriculture and Agricultural Science Procedia, 8, 252-256. doi: 10.1016/j.aaspro.2016.02.100.

Suplotova, L.A., Makarova, O.B., Sharuho, G.V., Koval'zhina, L.S. (2018). Rol' pitanija v profilaktike i korrekcii jododeficitnyh sostojanij na jendemichnoj territorii. Voprosy pitanija, 87(5), 27-36. doi: 10.24411/0042-8833-2018-10050 (in Russian). 
Technical consultation for the prevention and control of iodine deficiency in pregnant and lactating women and in children less than two years old. Geneva, World Health Organization, 2007 (To be published).

Tipsina, N.N., Komarova, O.Ju., \& Strupan, E.A. (2008). Tehnologicheskie osobennosti pektinosoderzhashhego syr'ja. N.N. Tipsina,. Vestnik Krasnojarskogo gosudarstvennogo agrarnogo universiteta, 1, 253-259 (in Russian).

Tonacchera, M., Dimida, A., De Servi, M., Frigeri, M. et al. (2013). Iodine Fortification of Vegetables Improves Human Iodine Nutrition: In Vivo Evidencefor a New Model of Iodine Prophylaxis. The
Journal of Clinical Endocrinology and Metabolism, 98(4), 99. doi: 10.1210/jc.2012-3509.

Trøan, G., Pihlava, J-M., Brandt-Kjelsen, A., Salbu, B., \& Prestløkkena, E. (2018). Heat-treated rapeseed expeller press cake with extremely low glucosinolate content reduce transfer of iodine to cow milk. Animal Feed Science and Technology, 239, 66-73. doi: 10.1016/j.anifeedsci.2018.02.011.

Usenja, Ju.S., \& Filatova, L.V. (2015). Novye vidy suhih zavtrakov funkcional'nogo naznachenija. Pishhevaja promyshlennost': nauka i tehnologii, 4(30), 82-85 (in Russian). 